DOI 10.14746/ssp.2019.4.5

\author{
Владимир Гуторов
}

Санкт-Петербургский государственный университет, Россия

ORCID: 0000-0001-8063-2558

\title{
О некоторых актуальных аспектах интерпретации либеральной традиции в России ${ }^{1}$
}

\begin{abstract}
Аннотация: В статье рассматриваются ключевые моменты трансформации либеральной традиции в России в контексте анализа основных направлений эволюции либерального идеологического дискурса и либеральной культуры в Западной Европе и США. Необходимость такого анализа определяется, прежде всего, тем, что с начала 1990-х годов западные либеральные стереотипы стали идеологической основой для новой российской политической элиты и доминирующей тенденцией государственной пропаганды. Однако часто упускается из виду главный факт: в XX веке российский либерализм был дважды скомпрометирован так, что в краткосрочной перспективе надежд на возрождение либеральных идей практически не остается. Кризис либеральной традиции обозначился и на Западе. Либерализм переживает там очень значительные трансформации, имеющие далеко идущие культурные и политические последствия. В частности, в конце XX - начале XXI вв. более активную роль в западном публичном дискурсе стали играть радикальные неоконсервативные версии идеологии, сочетающие консервативную программу политических реформ с сильной либертарианской (неолиберальной) риторикой, которая активно использовались правящими кругами США и Западной Европы для идеологического влияния на политические элиты как России, так и стран Центральной и Восточной Европы в период так называемых «бархатных революций». Одновременно в конце двадцатого века все яснее и определеннее выходили на передний план антилиберальные идеи и критика, которые всегда развивались параллельно с самим либерализмом и почти никогда не прекращали своего существования.
\end{abstract}

Ключевые слова: либерализм, консерватизм, социализм, посткоммунизм, революция, политические идеологии, демократия, капитализм

1 Статья подготовлена при поддержке Российского Фонда фундаментальных исследований и Экспертного института социальных исследований, проект № 19-011-31066 «Символическая политика в современной России: глобальные риски, гражданская идентичность и векторы исторической памяти».

Acknowledgements. The article was prepared with the support of the Russian Foundation for Basic Research and the Expert Institute of Social Research, project No. 19-011-31066 «Symbolic politics in modern Russia: global risks, civil identity and vectors of historical memory». 


\section{Введение}

И стория формирования и эволюции либеральных идей и политики в России является чрезвычайно поучительной в том плане, что именно в рамках данного направления свойственные всем российским идеологиям утопические настроения и иллюзии отличались особым драматизмом: неоднократно приближаясь к тому порогу, когда идея становится реальностью, либерализм снова и снова терпел позорное поражение от своих более удачливых идеологических и политических конкурентов и обрекал себя на весьма жалкую роль эфемерной оппозиции. Конкретные исторические обстоятельства и формы, в которые облекался крах отечественной либеральной идеологии и политики, свидетельствовали также о том, что сформировавшийся на протяжении XIX и XX столетий «либеральный интернационал» и его лидеры, игравшие ключевую роль в идеологическом и политическом дискурсах Западной Европы и США, никогда не были склонны преодолеть собственные русофобские предрассудки, глобальные претензии вкупе с региональным эгоизмом и оказать своим российским единомышленникам реальную и действенную поддержку.

В XX веке российский либерализм дважды скомпроментировал себя настолько, что в ближайшей перспективе надежды на возрождение либеральной идеи практически не остается. Современный отечественный книжный рынок буквально наводнен публикациями, авторы которых подробно и иногда вполне доказательно разъясняют читающей публике причины исторического поражения либерализма и не без основания рассчитывают на понимание с ее стороны.

«Либеральная революция», развернувшаяся в начале 1990-х гг. и вновь, как и в 1917 г., приведшая российское государство к экономической катастрофе, осуществлялась под лозунгом целенаправленного развала «советской тоталитарной империи», сразу оживив самые худшие подозрения и ассоциации относительно традиционного схематизма, инертности, теоретической бездарности и практического бессилия отечественных либеральных группировок, крикливо заявлявших о себе в этот период. В отечественной научной литературе постоянно витает вопрос - возможно ли рассматривать «либеральную революцию» в России как движение, направленное на восстановление политических и культурных традиций досовет- 
ского времени и, в конечном итоге, укрепления и дальнейшего развития экономической и военной мощи страны? Отрицательный ответ на этот вопрос связан не только с тем, крайне знаменательным, фактом, что эта революция началась с целенаправленного развала российской государственности. Но ведь пришедшие к власти в начале 1990-х гг. либералы выдвинули идею возврата страны в мировую цивилизацию! Однако с самого начала этот лозунг был насквозь анти-историчен и имел весьма специфическую идеологическую нагрузку.

При всех особенностях исторической судьбы, например, традиционную конфронтацию с Западом, имперская Россия, особенно в конце XVIII - начале XIX вв., становится органической составной частью европейской экономической и политической системы. Во второй половине XIX в. об этом свидетельствовали в равной степени и бурное развитие капиталистических отношений в пореформенный период, и система финансовых и военных альянсов между Российской империей и западными странами на рубеже XIX-XX вв. (например, знаменитый французский заем, позволивший царской России стабилизировать финансовую систему и справиться с первой революционной волной, вступление в Антанту и т.д.). Если бы не Октябрь 1917 г., Россия, оказавшись в числе стран-победительниц в Первой мировой войне, не только укрепила бы свои геополитические позиции, но и имела бы все шансы без революционных потрясений превратиться за короткий исторический промежуток времени в равного партнера любой великой державы, постепенно проводя экономическую модернизацию и политические реформы. После 1917 г., противопоставив себя Западу в качестве бастиона «мировой революции», советская Россия, тем не менее, вскоре вновь стала восстанавливать традиционные торговые и экономические связи с западными партнерами, хотя и всегда рассматривалась последними как потенциальный агрессор и источник социальных смут. Победа во Второй мировой войне и превращение СССР в мировую сверхдержаву, естественно, усилили и процесс его интеграции в мировую экономику, хотя отношение к нему западных стран как к очагу «коммунистической угрозы» в идеологическом плане не изменялось. Лозунги, выдвинутые российскими либералами, имели, следовательно, иную акцентировку, связанную с планом коренного изменения алгоритма экономического и политического 
развития страны на основе внедрения западных реформаторских рецептов и программ.

В свое время Октябрьская революция весьма рельефно выявила утопический характер либеральной программы тех политических партий, которые пришли к власти в феврале 1917 г. «Утопии, - отмечал Н. А. Бердяев, - плохо знали или забыли и слишком воздыхали о невозможности их осуществления. Но утопии оказались гораздо более осуществимыми, чем казалось раньше. И теперь стоит другой мучительный вопрос, как избежать окончательного их осуществления. Большевиков считали у нас утопистами, далекими от реальных жизненных процессов, реалистами же считали кадетов. Опыт жизни научает обратному. Утопистами и фантазерами были кадеты. Они мечтали о каком-то правовом строе в России, о правах и свободах человека и гражданина в русских условиях. Бессмысленные мечтания, неправдоподобные утопии! Большевики оказались настоящими реалистами, они осуществляли наиболее возможное, действовали в направлении наименьшего сопротивления, они были минималистами, а не максималистами. Они приспособлялись к интересам масс, к инстинктам масс, к русским традициям властвования. Утопии осуществимы, они осуществимее того, что представлялось “реальной политикой” и что было лишь рационалистическим расчетом кабинетных людей» (Berdiaev, 1990a, с. 37).

За десятилетия советской власти консервативные имперские инстинкты были прочно закреплены на идеологическом уровне и в повседневной практике. Тем самым усиливалась основа российского консервативного традиционализма, были сформированы экономические, социально-политические и психологические условия обеспечения преемственности с глубинными традициями российской политической культуры. В начале 1990-х гг. этим традициям был вновь брошен вызов, причем в тот исторический момент, который оказался чрезвычайно благоприятным для выдвижения альтернативной программы: российское государство переживало глубокий кризис ценностей, вызванный полной дезориентацией общественного сознания, которая стала закономерным результатом краха инициированной Горбачевым «перестройки».

Возникает естественный вопрос: в какой мере политическая философия либерализма разделяет вину либералов-политиков, тщетно пытавшихся в различные исторические эпохи применить ее в Рос- 
сии на практике? Или же для нашей страны будет вечно актуален «самый большой парадокс в судьбе России», чрезвычайно метко охарактеризованный Н. А. Бердяевым: «либеральные идеи, идеи права, как и идеи социального реформизма, оказались в России утопическими. Большевизм же оказался наименее утопическим и наиболее реалистическим, наиболее соответствующим всей ситуации, как она сложилась в России в 1917 году...», а «коммунизм оказался неотвратимой судьбой России, внутренним моментом в судьбе русского народа»? (Berdiaev, 1990b, с. 93).

\section{Политические метаморфозы западного либерализма}

Ответ на поставленные выше вопросы может быть получен, например, путем сравнения России и современных западных либеральных государств, прошедших период индустриальной модернизации и вступивших на рубеже XX-XXI вв. в постиндустриальную эру. И в Великобритании, ставшей в XIX в. своеобразной лабораторией, в которой принципы либерализма успешно прошли историческую проверку, и во многих других западноевропейских странах, а также в США повсеместно распространено убеждение, что именно эти принципы лежат в основе как экономической эффективности, так и стабильности демократических институтов и системы административного управления. Соответственно, в том случае, если программа либерализации экономики и политической системы терпит неудачу, как это случилось в посткоммунистической России, возникающие в общественном сознании различные варианты анализа причин неэффективности либерализма во многом определяются идеологическими предпочтениями участников многочисленных дискуссий. Однако все существующие на данный момент способы объяснения сводятся к двум основным: либо либеральные принципы не являются универсальными, либо исторические особенности социально-политического и экономического развития страны («русский путь») и сформировавшаяся в специфических условиях ментальность россиян исключают возможность их реализации в ближайшей перспективе. При этом большинство сторонников второго варианта - как ученые, так и практические политики - постоянно выделяют в качестве главного довода отсутствие в России право- 
вой культуры западного типа, который был всесторонне обоснован еще в начале XX века авторами знаменитого сборника «Вехи» (Manifesty..., 2009).

В истории российской философской и политической мысли обозначенные выше вопросы постоянно возникали в том или ином виде в спорах сторонников либерализма и его принципиальных противников со второй половины XVIII и до конца XX столетий. Однако адекватный научный анализ этих споров во многом зависит от возможности сформировать исходную «классификационную модель», с помощью которой может быть разработана приемлемая в научном плане типология российского либерализма, объединяющая исторический и сугубо теоретический подходы. Решение этой проблемы осложняется чрезвычайным многообразием научных и философских интерпретаций как самого понятия «либерализм», так исторических истоков и смысловой структуры либеральной идеологии.

Научная и философская литература, посвященная либерализму безбрежна: даже для простого и поверхностного изучения монографий и статей, появившихся во второй половине XX - начале XXI вв., может не хватить научной жизни. Однако уже беглого взгляда на опубликованные книги и статьи вполне достаточно, чтобы прийти к совершенно определенному и далеко не утешительному выводу: универсальных типологий либерализма до сих пор не существует. Линии, разделяющие его интерпретации, проходят по многим сферам жизнедеятельности и культуры - экономической, политической, социальной; деятельности интеллектуальной - философии, истории, политике; по регионам и странам; историческим этапам эволюции общественной мысли и т.д. Обсуждая сравнительно недавно эту проблему, М. Фриден вполне справедливо и весьма остроумно отмечал: «Не существует единственной, недвусмысленной вещи, называемой либерализмом. Все либерализмы, которые когда-либо существовали и продолжают существовать, выбирают - обдуманно или бессознательно - определенные номера из накопившегося и переполненного либерального репертуара и откладывают в сторону прочие то ли потому, что некоторые элементы несовместимы с другими, то ли из-за изменения интеллектуальных мод и практик. Как следствие, множество систем верований и теорий гнездятся под заголовком “либерализм" и ни одна из них не может вместить в себя все возможности - идеи и разновидности политического устройства 
- которые могут в себе заключать или сам термин в своей максимальной, но гипотетической полноте, или же те виды либеральных политических практик, которые накопились во времени и в пространстве» (Freeden, 2015, с. 5).

По справедливому замечанию Э. Фосетта, «Либерализм не обладает мифом о своем происхождении и не имеет года рождения. Хотя его истоки простираются настолько же далеко, насколько вас могут увлечь собственные энергия и любопытство, он возникает и как политическая практика распространяется по Евро-Атлантическому миру только после 1815 года. Либерализм отвечал новым условиям общества, заряженного капитализмом и потрясенного революцией, в котором материальные и этические изменения, хорошо это или плохо, рассматриваются как неотъемлемые» (Fawcett, 2014, c. XII; cf.: Kahn, 2005). Однако уже на раннем этапе начинают проявляться значительные различия в формировании либеральных культур и традиций. В Европе, в отличие от США, эволюция либеральной традиции оказалась гораздо более сложной и противоречивой: «многое из традиции либерализма было воспринято, но само название ассоциировалось в умах многих с элементами, которые отвергались. Многие из тех, кто, как и в США, называли себя либералами, отмежевывались от существенных частей традиции. Определенные элементы либерализма, в особенности высокая оценка материального благосостояния индивидов, вступили в комбинацию с традицией, которая вдохновлялась и развивалась в форме негативного ответа на неспособность либерализма вытащить из нищеты остаточное меньшинство населения... Традиция европейского либерализма подвергалась суровой критике в интеллектуальных кругах в конце девятнадцатого века вследствие противоречия между предсказываемыми им выгодами и его неспособностью эти выгоды создавать» (Shils, 1981, с. 224). Так, постепенно на Западе формировались группы, которые Э. Шилз именует «коллективистскими либералами» (collectivistic liberals), близкими по идеологическим ориентациям к «демократическим социалистам» (democratic socialists) (Shils, 1981, с. 227).

Такого рода идеологические метаморфозы, естественно, не могли не «прагматизировать» до самой крайней степени теоретические подходы к определению самого понятия «либерализм», нередко придавая ему чисто утилитарный характер. «Можно сказать, что ли- 
берализм, - отмечает Т. Магнелл (T. Magnell), - не является тем, чем он обычно представляется. Термин “либеральный” становится чемто приближающимся к свободному использованию власти, в особенности теми политиками, которые готовы продвигать программы, пользуясь деньгами других людей. Каким образом термин оказывается узурпированным сторонниками экспроприации - это, конечно, любопытно, но не является беспрецедентным для терминов, стремящихся стать почетными. В любом случае присвоение слов только усиливает значение защиты от посягательств на индивидуальные свободы» (Liberalism. New Essays..., 2000, c. 1; cf.: Autonomy..., 2005; Thompson, 2011). Признавая справедливость такого рода аналитики, возможно прийти к следующему выводу: общая тенденция эволюции либеральной идеологии и политики вполне может рассматриваться как процесс отхода от классической традиции, связанной с именами Д. С. Милля и Б. Констана и ее постепенного перерождения, которое многие критически настроенные современные ученые склонны иногда квалифицировать как полное вырождение.

Тем не менее в конце XX века некоторым, даже наиболее выдающимся теоретикам, еще представлялось, что в общем балансе исторических побед и поражений либерализм оказался более устойчивым в историческом и политическом плане по сравнению, например с социализмом. Как отмечал Джералд Гаус, «В свете тревог, вернее, уныния либералов на протяжении большей части первой половины двадцатого века, либералы в преддверии следующего столетия могут вполне разумно и с полным основанием чувствовать, что у них есть право устроить настоящий праздник. Двадцатый век был до удивления либеральным веком. Либерализм, по-видимому, победил социализм, соперника, который так привлекал, но также беспокоил Хобхауса и Дьюи. Консенсус относительно преобладания либеральных идеалов свободы и рынков представляется почти универсальным. Во многом то, что сегодня называется “социализмом”, является своего рода левым либерализмом. Сегодняшние демократические социалисты, выступающие за щедрое государство всеобего благосостояния и здоровую демократическую жизнь в рамках общества, по сути, основанного на рынке и частной собственности, стоят гораздо ближе к новым типам либерализма Хобхауса и Дж. А. Хобсона, чем к социализму Карла Маркса или даже социализму Дж. Д. Х. Коула. И действительно, либеральная мысль 
настолько доминирует, что многие социалисты принимают одну из версий либеральной теории социальной справедливости Джона Ролза. Различие между “эгалитарной либеральной” и социалистической теориями справедливости часто невозможно установить» (Gaus, 2001, c. 14; cf.: MacIntyre, 1988, с. 392).

Однако в конечном итоге это все же была «пиррова победа»: на рубеже XX - начале XXI вв. наиболее активную роль в общественном дискурсе Запада стали играть радикальные неоконсервативные версии идеологии, сочетавшей консервативную программу политических реформ с ярко выраженной либертарианской (неолиберальной) риторикой, которая активно использовалась правящими кругами США и Западной Европы для идеологического воздействия на политические элиты стран Центральной и Восточной Европы в период так называемых «бархатных революций». «Революция в Центральной Европе, - писал Р. Бейнер, - приветствовалась либеральным, рыночно-ориентированным Западом, от всей души поздравлявшим себя. Такого рода поздравления, как представлялось, были вполне оправданы, во-первых, потому, что Запад “выиграл" войну определенного рода, которая велась в предшествующие четыре десятилетия; а во-вторых, потому, что экономический динамизм либеральных обществ, как полагали, был решающим признаком превосходства Запада над Востоком, обеспечивающим победу в этой войне» (Beiner, 1995, с. VIII).

Но одновременно все более явственными становились противоречия современного либерализма как в политическом, так и в этическом и культурном плане. «Другой глубокий парадокс современного либерального упорядочивания жизни, - отмечает Р. Бейнер, - состоит в том, что, усиливая в высшей степени ограниченное видение достоинства и уникальности индивида в рамках его или ее отдельной субгруппы, он одновременно предлагает коллективный образ жизни (“американизм”), который, быстро распространяясь, опутывает земной шар... Либерализм не в меньшей степени, чем социализм, феодализм или любой другой социальный порядок, - это глобальное устройство, т.е. образ жизни, который исключает другие образы жизни» (Beiner, 1995, с. 24). Как свидетельствует опыт эволюции идеологического дискурса на Западе со второй половины XX века, инерция фундаментального скептицизма в отношении теоретических и практических возможностей либеральной идеологии ока- 
залась настолько мощной, что и в начале XXI века альянс ученых и философов, выступающих против направления, именуемого ими «гегемонистским либерализмом», продолжал только укрепляться.

Одним из важных моментов этого процесса стала разработка своеобразной философии и «историософии» антилиберализма в многочисленных трудах экономистов, социологов, философов и политических теоретиков, критиковавших либерализм не только с учетом современных реалий, но стремившихся опираться на давнюю, восходящую к эпохе Просвещения традицию неприятия либеральной философии. «Гегемонистские либералы, - отмечает С. Вольф-Девин, - стремятся распространить либеральные принципы на любую сферу жизни, даже на частные ассоциации, такие как семья и церковь. Конечно, проталкиваясь все дальше и дальше, гегемонистский либерализм перестает быть либеральным вовсе, поскольку ему не удается продемонстрировать какое-либо уважение к предпочтениям и представлениям о совести людей, чуждающихся либерализма» (Wolf-Devine, 2003, с. 42).

Антилиберальный взгляд на исторический процесс состоит в том, что процесс либерализации и сам либерализм как направление экономической и политической мысли и практики, с точки зрения его противников, не всегда развивались по восходящей линии в духе книги Френсиса Фукуямы «Конец истории и последний человек» (Fukuyama, 1992). Со второй половины XVIII в. его развитие действительно было поступательным, но к концу XIX в. векторы исторического развития резко изменились в неблагоприятном для либерализма направлении. Некоторые экономисты (например, Дэвид Хендерсон и др.) рассматривают саму идею «неолиберальной гегемонии» как пропагандистский миф, подчеркивая, что политика британских неоконсерваторов в 1979-1990 гг. была лишь отчасти либеральной и затрагивала только некоторые отрасли производства, в то время как в других сферах социальной политики (например, в сфере науки) она имела сугубо дирижистский характер (Henderson, 2001, с. 8-10). К началу XXI в. «характерное большинство позиций по экономическим вопросам является анти-либеральным» (Henderson, 2001, с. 13).

В целом, в начале XXI в. антилиберализм во многом отличается от аналогичных направлений, которые возникли четверть века назад. Д. Хендерсон выделяет три его современные, весьма существенные 
отличительные черты: 1) Рост сторонников экономической политики советского и (или) китайского типа; 2) Резкое усиление критики неолиберальных реформ; 3) Увеличение стран, групп и ассоциаций, причисляющих себя к жертвам политики неоконов и выступающих за активное государственное вмешательство в регулирование экономики и других сфер общественной жизни (Henderson, 2001, с. 21). Иными словами, антилиберализм как направление общественной мысли и социальной политики отнюдь не пошел на убыль.

\section{Исторические судьбы русского либерализма}

Исторически обусловленные трансформации, происходившие с либерализмом на Западе на протяжении, по крайней мере, трех последних веков, имеют принципиально важное значение для современных исследователей русского либерализма, прежде всего, потому, что многие охарактеризованные выше линии эволюции западной либеральной и антилиберальной традиций воспроизводились в России на том же витке исторической спирали, одновременно демонстрируя ярко выраженную историческую специфику. Последняя оказалась настолько сложной, что в современной отечественной научной литературе многочисленные попытки разработать типологию русского либерализма, как правило, оказывались или незавершенными, или прямо неудачными. Поэтому нередко возникает искушение отдавать пальму первенства трудам тех западных ученых, которые хорошо знакомы и с истоками русской либеральной традиции, и современной философской полемикой. Одним из них, бесспорно, является Клаус фон Бейме. В работе «Политические теории в России. 1789-1945» он отмечал, что в сравнительной перспективе, при всем многообразии русского теоретического ландшафта, на международном уровне интерес представляли только христианская религиозная мысль «правого толка» и левая социалистическая и анархистская мысль. «Лишь русские либералы оставались без внимания», поскольку трудно ответить на вопрос - применимы ли были вообще к России традиционные для Запада категории «либерализм/радикализм, консерватизм, социализм/анархизм/коммунизм» (Веуте, 2001, с. 10-11). «В России в эпоху царя Александра [I] имелись, как в Германии и Испании, предпосылки 
для “чиновничьего либерализма” (Beamtenliberalismus). M. М. Сперанский (1808-1812) как ведущий государственный деятель представил царю реформаторские законы. Конституционная монархия, которая в Западной Европе привела к компромиссу между революцией и монархическим принципом, не могла возникнуть в России ввиду отсутствия предпосылок для национального представительства... Система земств до 1864 г. не получила ни единого шанса, и до 1906 г. в первой Думе отсутствовало представительство нации в целом» (Веуmе, 2001, с. 8). «Характер развития мысли западников, - продолжает К. фон Бейме, - лишь изредка трансформировался в либерализм. Гегельянство приобрело либеральное направление лишь в его правогегельянском варианте, как, например, у Чичерина» (Веуте, 2001, с. 29). Идеи Чичерина, Ковалевского, Кистяковского и Струве объединяются им в специальной главе под рубрикой «конституционные либералы», значительная часть которых, по его мнению, в дальнейшем эволюционировала в либерально-консервативном направлении. «В России, - отмечает фон Бейме, - либеральному консерватизму чичеринской чеканки не было суждено даже видимости процветания как [это было] в Пруссии. Лишь только либералы слегка обозначали пожелания конституции, они увольнялись со службы. И все же они становились консервативными. Такие ультра-реакционеры как Катков и Победоносцев когда-то начинали в качестве либералов. Либералы не заходили слишком далеко вправо, но стремились оставаться способными к диалогу в целях поддержки автократии» (Beyme, 2001, с. 40-41; ср.: Walicki, 2015, c. $447-449)$.

Так или иначе, сама по себе проблема определений и классификаций русского либерализма оказалась изначально крайне запутанной и остается таковой и сегодня. И в наши дни, как и в XIX в. идут бесконечные споры между сторонниками и противниками либерализма относительно того, кого именно в России следует именовать «подлинным либералом».

Одна из важнейших особенностей российского идеологического дискурса состояла и состоит в том, что его эволюция зачастую выглядит как наглядное опровержение знаменитого тезиса К. Маннгейма, сформулированного им в своей известной работе «Идеология и утопия»: «Консервативное мышление не склонялось... к созданию идей. В эту сферу борьбы его едва ли не насильно ввел его 
либеральный противник. Своеобразие духовного развития как будто и состоит именно в том, что темп и форму борьбы диктует противник, выступивший последним. Конечно, дело обстоит совсем не так, как это стремится доказать “прогрессивное мышление”, согласно которому право на существование имеет лишь новое, а все остальное постепенно отмирает, в действительности же под воздействием нового старое должно постепенно преображаться и приспосабливаться к уровню своего последнего противника» (Mannheim, 1998 , с. 208).

В России, напротив, либерализм в XVIII-XX вв. развивался именно как ответная реакция на нападки со стороны гораздо более мощных консервативных, а в дальнейшем и социалистических противников и конкурентов. Решающая причина такого положения вещей определялась, конечно, не столько особенностями отечественной «политической ментальности», сколько спецификой социально-политического устройства, формировавшего соответствующий тип сознания. «В России, - отмечал А. Д. Градовский, видный теоретик русского либерального консерватизма, - соотношение... двух элементов: сословий и бюрократии, должно было определиться иначе, чем на Западе, т.е. в пользу бюрократии, начала приказного... Общее направление законодательства в XIX столетии клонилось на пользу приказного начала и административной опеки» (Gradovkij, 1901, с. 290-291). Результатом приказного управления и административной опеки стало формирование духовной атмосферы, в которой либеральные идеи свободы, конечно, развиться не могли: «Общественного голоса не слышно было нигде; не было его на суде при формах прежнего процесса; не было его в печати, стесненной до последних пределов; не было его в учреждениях, где все сословия совещались бы о своих пользах; не было и самых учреждений общественных. В условиях обрядового, формального государства каждый неделимый осужден был жить “особо”, сам по себе, не образуя с другими общественных соединений, не воспитываясь в кругу дел общественных, не черпая из общественных явлений никаких живых впечатлений, под влиянием которых образуется склад деятеля общественного. Напротив, каждый уходил в свою скорлупу, в свой внутренний мир и из всех общественных влияний знал влияние тесного кружка согласно мыслящих. При такой обособленности всякое миросозерцание должно было получить чисто субъек- 
тивный характер; никакая идея не могла быть возведена на степень общественного начала, не могла быть проверена действительными общественными потребностями и быть переработана согласно с последними» (Gradovkij, 1901, с. 357).

Постепенно в русской общественной мысли сформировалось сверхмощное антилиберальное интеллектуальное поле, временами напоминавшее «черную дыру», в которой не только бесследно исчезали всякие сколько-нибудь положительные характеристики либеральной философии и культуры, но и виртуально стирались противоположности, противоречия, разногласия и оттенки практически всех направлений мысли - от славянофильства и западничества до ортодоксального монархизма и радикального социализма - уничтожались любые благие порывы, здравые научные суждения и моральные поступки. Доминирующую роль на этом поле играла идея об антинародном характере либерализма, в рамках которой «народ» противопоставлялся «образованному обществу», «интеллигенции» или «публике». Внешние контуры антилиберального поля были определены сначала П. Я. Чаадаевым, а в дальнейшем совершенно различными по характеру и культурным ориентациям интеллектуалами, такими как А. И. Герцен, Ф. И. Тютчев, В. П. Мещерский, К. П. Победоносцев и многими др. Общую тональность задавали характеристики либеральной ментальности, весьма энергично обрисованные, например, крайним консерватором князем В. П. Мещерским. «Совершенно ясно, - писал Мещерский, - что слово “либерализм” имеет вполне определенный образ, хотя самый нелепый, и можно бы взяться перечислить весь нехитрый катехизис нашего “либерализма”, который по своей несложности и соблазнительной простоте так доступен всякой самой нетвердой голове. Тут не нужно ни знания жизни, ни опыта, ни убеждений, ни таланта, ни практических знаний - это талисман, который дает возможность писать много людям, лишенным всего вышепоказанного» (Mescherskij, 2010, с. 331)². Как

2 По-видимому, именно кн. Мещерский, дошедший в своих инвективах против российской чиновной и титулованной интеллигенции до прямых ее обвинений в национальной измене, является праотцом той знаменитой формулы, которая в 1946 г. была отчеканена в романе Э. М. Ремарка «Триумфальная арка»: «Vaterlandsverrat als eine Art von Patriotismus» - «предательство Родины как разновидность патриотизма» (Mescherskij, 2010, с. 336-338, 321-322; Remarque, 1988. c. 311). 
отмечал А. Д. Градовский, цель такого рода характеристик - убедить всех русских людей в том, что «каждый либерал есть западник; ergo, каждый либерал есть глупец и урод, изменяющий своим народным началам, своей родине, вере своих отцов. Это как бы униат, подчиняющейся чужой духовной власти, сохраняя только некоторые формы православия. Отсюда уже само собою следует, что все стремления “либералов” клонятся к одной конечной цели - к извращению всего склада русской жизни на западный лад. Дальше этого “анализ” нейдет. Другого толкования слово “либерал” не имеет. Но не мало ли этого? Не имеет ли это слово какого-нибудь самостоятельного значения, независимо от западнических стремлений? Такого самостоятельного, неподставного, так сказать, определения нам не дают. Поэтому, мы поневоле должны идти путем собирания отдельных признаков, лучше сказать, отдельных обвинений, обращенных против либералов» (Gradovkij, 1901, с. 394-395).

В качестве одного из следствий на рубеже XIX-XX веков в русской общественной мысли полностью сформировалась полемическая традиция, которую трудно назвать творческим спором, философским диалогом или политической дискуссией, поскольку она больше напоминала обмен стереотипными инвективами, которыми представители противоположных идейных направлений, постоянно, «как говорится, машинально» (А. С. Пушкин), обменивались на протяжении многих десятилетий, создавая у современников, а в дальнейшем и у потомков устойчивое ощущение дежавю. На резкости Ф. М. Достоевского против либералов в «Дневнике писателя» и его почти экзальтированные призывы «смириться» и вновь найти опору в глубоких христианских корнях русского народа, в которых явно ощущалось влияние идей, сформулированных славянофилами и Тютчевым, теоретики либерального консерватизма Кавелин и Градовский отвечали спокойно, твердо и вполне справедливо: «Мы, русские, - народ действительно полудикий с крайне слабыми зачатками культуры»; «Общественные идеалы нашего народа находятся еще в процессе образования, развития. Ему еще много надо работать над собою, чтоб сделаться достойным имени великого народа. Еще слишком много неправды, остатков векового рабства, засело в нем, чтоб он мог требовать себе поклонения и, сверх того, претендовать еще на обращение всей Европы на путь 
истинный, как это предсказывает г. Достоевский» (Kavelin, 2013, c. 1017; Gradovkij, 1901, c. 381).

К началу XX в. существенное отличие России от Западной Европы и США заключалось в том, что процесс формирования политических партий в эпоху первой русской революции во многом определялся политическими радикалами: ультра-революционной тактике левого крыла РСДРП (большевиков) и эсеров противостоял ультрареакционный «Союз русского народа», лидеры которого апеллировали к самодержавию как единственному центру силы, способному справиться с «марксистскими смутьянами» и с руководителями «масонского заговора», верховодящими в Государственной Думе. В этих условиях идеи и политика российских либеральных партий, направленные на создание в России конституционного режима, выглядела визионерской и, как и предсказывал Макс Вебер в знаменитой переписке с русскими либералами, была заранее обречена на провал, если только они не переходили на более консервативные позиции. «Чем более социалистическим становился радикализм в России, - отмечает К. фон Бейме, - тем больше либералы ориентировались в направлении консерватизма. “Либеральный консерватизм” (“Liberal-Konservatismus”) был излюбленной самохарактеристикой (Selbstbeschreibung) для этой концепции от Чичерина до Струве. В условиях все более сгущавшейся автократии консерватизм-статус кво (ein Status-quo-Konservatismus) не мог иметь успех. Даже консерватизм становился оппозиционным по мере того, как он все больше проникался намерением быть романтически-славянофильским и по большей части отчужденным от государства. Поэтому в рамках такой системы либеральные консерваторы должны были брать на себя функцию консерватизма. Струве однажды заметил, что русский народ слишком долго топтался на месте, чтобы позволить себе быть консервативным» (Веуте, 2001, c. 55).

На наш взгляд, все эти обстоятельства не вносили ясность в понимание того, что собой представляет либерализм на русской почве, но, наоборот, создавали дополнительные трудности в решении принципиально важного вопроса: «Одно из двух: или Россия в самом деле такая страна, что в ней все делается навыворот, или в самой оценке занимающего нас факта есть какая-нибудь фальшь» (Gradovkij, 1901, c. 354). 


\section{Заключение}

Обозначенные выше теоретические наблюдения за эволюцией русского либерализма постоянно воспроизводятся в современных политико-философских дискурсах и по-прежнему сохраняют актуальность, поскольку они являются отражением вполне реального процесса, предпосылки которого наметились в Западной Европе и США со второй половины XX в. Результатом данного процесса становится, прежде всего, основополагающий консенсус относительно всеобщих политических ценностей - равенства, гражданских прав, демократических процедур принятия решений на базе признания существующих социальных и политических институтов. Был провозглашен курс на прогрессирующую стабильность, взаимопроникновение взглядов представителей различных классов на принципиальные социально-политические проблемы, постепенное исчезновение конфликтов (Веуте, 2013, р. 29-33).

Разумеется, в посткоммунистической России 1990-х гг. ни о каком гражданском обществе и идеологическом консенсусе никто из ученых, знакомых с послевоенной историей, всерьез рассуждать не может. Советская система с самого начала была воспроизведением на новом витке исторической спирали бюрократического, «приказного» типа государственного и политического управления, хорошо обрисованного А. Д. Градовским. В большинстве посткоммунистических стран идеал гражданской свободы также оказался первоначально реализованным в новом государственном аппарате и новой бюрократии. По своему характеру эти социальные структуры составляли явный контраст западным традициям. Причины, обусловившие новый, слегка либерализированный пароксизм традиционной бюрократической матрицы, были, конечно, различными. В России с ее традициями патриархальной монархической и тоталитарной коммунистической политической культуры концепция либеральной демократии и гражданского общества, будучи встроенной в догматический псевдолиберальный проект, оказалась еще более идеологизированной и далекой от реальности. Антитоталитарная направленность этой концепции с примесью традиционной антикоммунистической риторики приводила, как правило, к тому, что она искажала и камуфлировала реальный процесс разложения советского общества в направлении форми- 
рования неономенклатурного государства, нуждавшегося именно в идеологических мутантах либерализма и демократии, а не в действительном развитии гражданского общества в качестве противовеса государству.

Нет никаких сомнений в том, что западный вариант модернизации и сам почти идиллический образ Запада, который когда-то был столь привлекательным для многих поколений русских либералов, почти полностью себя исчерпали. В современном мире возникают новые альтернативы как либеральному космополитическому мультикультурализму, доминировавшему на протяжении последних нескольких десятилетий, так и тому тупиковому варианту развития, который был избран посткоммунистической неономенклатурной элитой в 1990-е гг. с целью установления тотального контроля над национальными ресурсами и политическим процессом. Результатом псевдореформ стало вполне закономерное восстановление структурных элементов, близко напоминающих нам недавнее прошлое.

\section{Библиография}

Autonomy and the Challenges to Liberalism: New Essays (2005), eds. J. Christman, J. Anderson, Cambridge.

Beiner R. (1995), What's the Matter with Liberalism?, Berkeley-Los Angeles-Oxford.

Berdiaev N. (1990a), Novoje srednevekovje. Razmyshlenije o sud'be Rossii i Evropy [The New Middle Ages. Deliberation on the Fate of Russia and Europe], Moscow [Бердяев Н. (1990а), Новое средневековье, Москва].

Berdiaev N. A. (1990b), Istoki i smysl russkogo kommunizma [The Beginning and Meaning of the Russian Communism], Moscow [Бердяев Н. А. (1990b), Истоки и смысл русского коммунизма, Москва].

Beyme K. von. (2001), Politische Theorien in Russland. 1789-1945, Wiesbaden.

Beyme K. von. (2013), Liberalismus. Theorien des Liberalismus und Radikalismus im Zeitalter der Ideologien. 1789-1945, Wiesbaden.

Fawcett E. (2014), Liberalism. The Life of an Idea, Princeton.

Freeden M. (2015), Liberalism. A Very Short Introduction, Oxford.

Fukuyama F. (1992), The End of History and the Last Man, New York.

Gradovkij A. D. (1901), Sobranije sochinenij, T. 6 [Works, vol. 6], ed. A. A. Shahmatov, St. Petersburg [Градовский А. Д. (1901), Изд. А. А. Шахматов, Т. 6, Санкт-Петербург]. 
Gaus G. (2001), Ideological Dominance through Philosophical Confusion: Liberalism in the Twentieth Century, in: Reassessing Political Ideologies. The Durability of Dissent, ed. M. Freeden, London-New York, pp. 13-34.

Henderson D. (2001), Anti-liberalism 2000. The Rise of New Millenium Collectivism, London.

Kahn P. W. (2005), Putting Liberalism in Its Place, Princeton.

Kavelin K. D. (2013), Gosudarstvo i obschina [State and Community], eds. V. B. Trofimova, O. A. Platonov, Moscow [Кавелин К. Д. (2013), Государство и община, под ред. В. Б. Трофимовой, О. А. Платонова, Москва].

Liberalism: New Essays on Liberal Themes (2000), eds. J. Narveson, S. Dimock, Dordrecht.

MacIntyre A. (1988), Whose Justice? Which Rationality?, Notre Dame-Indiana.

Mannheim K. (1998), Ideology and Utopia: An Introduction to the Sociology of Knowledge, London-Henley.

Manifesty russkogo liberalizma. Problemy idealizma. Vehi. Iz glubiny (2009) [Manifestos of the Russian Idealism. The Problems of Idealism. Milestones. De Profundis], ed. V. V. Sapov, Moscow [Манифесты русского либерализма. Проблемь идеализма. Вехи. Из глубины, под ред. В. В. Сапова, Москва].

Mescherskij V. P. (2010), Za velikuju Rossiju. Protiv liberalizma [For the Great Russia. Against Liberalism], eds: Y. V. Klimakov, O. A. Platonov, Moscow [Мещерский В. П. (2010) За великую Россию. Против либерализма, под ред. Ю. В. Климакова, О. А. Платонова, Москва].

Remarque E. M. (1988), Arc de Triomphe. Roman. Mit einem Nachwort von Tilman Westphalen, Köln.

Shils E. (1981), Tradition, Chicago.

Thompson W. (2011), Ideologies in the Age of Extremes: Liberalism, Conservatism, Communism, Fascism 1914-1991, New York.

Walicki A. (2015). The Flow of Ideas. Russian Thought from the Enlightenment to the Religious-Philosophical Renaissance, Frankfurt am Mein.

Wolf-Devine C. (2003), The Hegemonic Liberalism of Susan Moller Okin, in: Liberalism at the Crossroads. An Introduction to Contemporary Liberal Political Theory and Its Critics. Second Edition, ed. Chr. Wolfe, Lahnam-BoulderNew York-Oxford, pp. 41-60.

\section{On some actual aspects of the interpretation of the liberal tradition in Russia}

\section{Summary}

The article examines the key moments of the transformation of the liberal tradition in Russia in the context of analysis of the main directions of the evolu- 
tion of liberal ideological discourse and liberal culture in Western Europe and the United States. The need for such an analysis is determined, primarily, by the fact that since the early 1990s the Western liberal stereotypes became ideological basis for the new Russian political elite and the dominant trend of state propaganda. However, the main fact is often overlooked: in the XX century Russian liberalism has twice been compromised so that in the short-term the hopes for the revival of the liberal ideas are left. The crisis of the liberal tradition delineated also the West. Liberalism is undergoing there very significant transformation, with far-reaching cultural and political implications. In particular, at the end of XX - beginning of XXI cc. more active role in Western public discourse began to play the radical neo-conservative versions of an ideology that combined conservative program of political reforms with a strong libertarian (neoliberal) rhetoric, which is actively used by the ruling circles of the USA and Western Europe for ideological influence on the political elites of Russia as like as the Central and Eastern Europe during the so-called "velvet revolutions". At the same time in the late twentieth century, more and more clearly and sharply came to the fore anti-liberal thought and criticism that has always evolved in parallel with liberalism itself and almost never stopped its existence.

Key words: liberalism, conservatism, socialism, post-communism, revolution, political ideologies, democracy, capitalism

\section{W sprawie niektórych aktualnych aspektów interpretacji tradycji liberalnej w Rosji}

\section{Streszczenie}

W artykule rozpatruje się kluczowe momenty transformacji tradycji liberalnej w Rosji w kontekście analizy głównych kierunków ewolucji liberalnego dyskursu ideologicznego oraz kultury liberalnej w Europie i USA. Konieczność tejże analizy wynika przede wszystkim stąd, iż od początku lat 90-tych XX stulecia zachodnie stereotypy liberalne stały się podstawą ideologiczną dla nowej rosyjskiej elity politycznej oraz dominującą tendencją propagandy państwowej. Zarazem często traci się z pola widzenia główny fakt: w wieku XX liberalizm rosyjski uległ dwukrotnej kompromitacji, toteż nadzieje na odrodzenie idei liberalnych w perspektywie krótkookresowej praktycznie nie istnieją. Kryzys tradycji liberalnej zaznaczył się również na Zachodzie. Liberalizm przeżywa tam głęboko znaczące przemiany, posiadające daleko idące następstwa kulturowe i polityczne. W szczególności, w końcu XX i na początku XXI wieku bardziej aktywną rolę w zachodnim dyskursie publicznym zaczęły odgrywać radykalne, neokonserwatywne wersje ideologii, łączące konserwatywny program reform politycznych z silną retoryką libertariańską (neoliberalną), którą kręgi rządzące USA oraz Europą Zachodnią aktywnie wykorzystywały w celu ideologicznego oddziaływania zarówno na elity polityczne Rosji, 
jak i państw Europy Centralnej i Wschodniej w okresie tzw. aksamitnych rewolucji. Zarazem w końcówce XX wieku coraz jaśniej i wyraźniej na pierwszy plan wysunęły się idee antyliberalne i krytyka antyliberalna, które zawsze rozwijały się równolegle w stosunku do samego liberalizmu i których istnienie niemal nigdy nie uległo przerwaniu.

Słowa kluczowe: liberalizm, konserwatyzm, socjalizm, postkomunizm, rewolucja, ideologie polityczne, demokracja, kapitalizm 
